\title{
The stunning birth of tourism on the islands of Ibiza and Formentera
}

\author{
Joan Carles Cirer-Costa \\ jccirer@gmail.com
}

\begin{abstract}
Ibiza, one of the largest and most celebrated tourist destinations in the world, sprang into life in the midst of the Great Depression. At that time, the tourist business was changing rapidly, and Ibiza's entrepreneurs succeeded in detecting this and doing everything within their power to exploit it to the maximum, creating a tourist offer of international standing in just a few years. This article analyses the birth of tourism on the islands of Ibiza and Formentera from an economic point of view (i.e., as a function of supply and demand), focusing on three core elements: economic growth, island environment, and the introduction of tourism. The 1930-1934 tourism boom in Ibiza and Formentera was made possible, above all, because of the factor of entrepreneurship — an element that is typically left out of most models that analyse tourism development.
\end{abstract}

Keywords: Ibiza, Formentera, history of tourism, innovation, island development, tourism destination, tourism entrepreneurs

https://doi.org/10.24043/isj.149 • Received January 2020, Early access February 2021

(C) Island Studies Journal, 2021

\section{Introduction}

Ibiza and Formentera are two islands closely linked to tourism, which lies at the core of their economy and society and has ultimately come to shape the islands' very identity. This dominance, however, is not a phenomenon that can be regarded as exclusive by any means. Indeed, it is shared with other islands in the Mediterranean and around the world where the population has similarly taken on and internalised a dependence on tourism (Baldacchino, 2008; Butler \& Carlsen, 2011; Karampela et al., 2017).

In this article, we will be analysing the birth of tourism in Ibiza and Formentera from an essentially economic point of view, i.e., as a result of the interaction between supply and demand. We propose that the key factor to begin with was the emergence of a new tourism demand, met in a handful of places where creative and innovative entrepreneurs were able to see that change was in the air, creating an offer which departed radically from earlier models. As will be seen below, the process was distinguished by a total lack of any kind of planning, with local businessmen determining the commercial framework and the geographical distribution of the new tourist destination as they went along. 


\section{Factors facilitating island tourism development}

This study sets out to analyse the development of an island economy resulting from the introduction of tourism through a process which unfolded over a very short period of time, specifically between 1930 and 1934, and in which all the initiative came from private entrepreneurs. In this respect, the study focuses on three core elements: economic growth, island environment, and the introduction of tourism.

The first of the three core elements, economic growth, has been explored from a wide range of perspectives in the academic world. Economic theory has studied growth through a fundamentally macroeconomic approach, operating at a very high level that is, however, poorly suited to the analysis of a small island economy without a public or financial sector. More useful are the contributions that have come from the field of economic history, in which many authors have analysed the growth of the economy in the first third of the $20^{\text {th }}$ Century. Their conclusions point to two primary causal factors of economic growth: technological progress (Mokyr, 1998, 2005; Toniolo, 1998) and the redeployment of productive factors from agriculture to industry and the service sector (Fuchs, 1965; Schettkat \& Yocarini, 2003). As we shall see, both of these factors were present in the case of Ibiza and Formentera.

The approach adopted in this study treats the individual entrepreneur as a primary agent of economic growth, regarding it as necessary to emphasise "[t]he distinctiveness (or eccentricity) of individual entrepreneurs" (Miskell, 2018, p. 214). This view follows in the wake of authors who have identified the valuable role that small businesses play in innovation, the discovery and exploitation of opportunities, and the creation of new markets (Acs \& Audretsch, 2005; Baten, 2003; Casson \& Lee, 2011; Eckhardt \& Shane, 2003). This type of entrepreneur always acts within a social environment that shapes and modulates their initiatives, thus giving rise to the notion of institutions as bodies that "provide the incentive structure of an economy" (North, 1991, p. 97).

These institutions in which the entrepreneur operates and develops occur at different geographical levels. Appearing at the highest level are the so-called "varieties of capitalism", which are expansive, overarching institutional forms that include the so-called "Mediterranean model". According to the canonical definition, the Mediterranean model is characterised by the importance of the traditional agrarian sector and by strong state interventionism (Hall \& Soskice, 2001). Given the geography in question, the Mediterranean model, in principle, should be applicable to the present object of analysis. In this case, however, appearances are deceiving. In fact, Ibiza and Formentera had their own particular institutional environment and a subculture that was clearly distinct from the one that existed at the level of the Spanish state, according to the sense proposed by Klyver and Foley (2012). The agriculture sector in both Ibiza and Formentera was very important, but it was engaged in very modern commercial agriculture, not backward subsistence agriculture. Also, the role of the public sector in the islands' economic development was negligible in the period under study and later became a genuinely negative factor (Cirer, 2019, 2020).

Being an island has two very distinct aspects: social and economic. With respect to the social aspect, the fact of being an island stamps a distinctive character on the population; it differentiates and identifies the population, especially when the island is small and its inhabitants only number in a few tens of thousands. In this case, it gives rise naturally to the relationships that distinguish an industrial district: "a socioterritorial entity which is 
characterised by the active presence of both a community of people and population of firms in one naturally and historically bounded area" (Becattini, 2004, p. 19). Such an environment promotes economic cooperation through the establishment of relationships of trust and confidence that replace the market (Besser \& Miller, 2011; Ottati, 1994, 2002; Sammarra \& Biggiero, 2001). Also, on Ibiza and Formentera, as on so many other islands, emigration formed an intrinsic part of the economic model, enabling informal relationships to extend thousands of kilometres by encompassing the ties formed by island natives who settled abroad but kept in close touch with their place of origin (Armstrong \& Read, 2000; Popp et al., 2006).

Important among the economic aspects of being an island are chronic shortages of resources and the issue of accessibility. While the resources of any island are particularly limited, an island that has something to sell also needs to ship its products abroad and receive vital supplies in exchange (Bertram \& Poirine, 2007; Karampela et al., 2014). In the present case, Ibiza was in a position to sell salt and agricultural products in international markets and it enjoyed relatively good accessibility because of its favourable geographical position and the variety and breadth of its merchant navy.

\section{Stages of tourism development}

The main analytical tool that will be used in the present study is a development model devised specifically to explain the tourism growth of destinations prior to World War II. This development model has three levels:

1) Non-tourism. Directly related to the economic development of the location. At this level, the first travellers of the adventurer/explorer type made use of the transport and accommodation resources which a non-tourism society had organised to meet its own needs and which made no allowances for tourists. For instance, transport calendars and timetables were set exclusively to meet the needs of local commerce, and restaurants, if any existed, served only local food.

2) Basic or limited tourism. At this level, there were now companies capable of transporting and accommodating travellers who wanted to "sightsee" without actually being an adventurer/explorer. These customers did not require a high level of convenience or comfort, either because they could not afford it or because they were willing to accept a certain level of inconvenience and lack of comfort in order to visit relatively unknown spots that piqued their innate curiosity. At this level, there were now a few specific means of transport for tourists, and tourists were able to afford some consumer goods of international quality. In general, this type of destination arises as a result of an adaptive response to demand pressures.

3) Advanced tourism. At this level, the destination enjoyed regular and comfortable communication links that were specifically adapted to the transport of tourists, and it possessed comfortable accommodation that could receive demanding customers who wanted to "enjoy" their holidays in an environment that was similar to their place of origin. Only destinations that reached this level were in a position to support effective promotional and marketing activities to ensure the maintenance of tourism demand and its long-term sustainability. The presence of a competent, well-publicised supply of transport and accommodation generated its own demand among potential customers who required a high level of comfort and convenience. In this case, entrepreneurs no longer offer an adaptive 
response, but rather engage in a creative effort, generating the necessary conditions for the emergence of a completely new market.

The model used in the present study is sequential, and is based on the prior existence of populated entities that engage in their own economic activity to which any tourism business is an addition. These entities have some type of attractive feature or features that generate tourism demand, such as landscapes, classical ruins, beaches, etc. The attractive power of these features determines the potential of a given location to become a tourist destination of the basic or advanced type, but it is a necessary condition, not a sufficient one. There will be no development of any sort if the demand is not satisfied with a qualified supply. This supply can be based on local resources or outside resources. In the former case, an integrated destination will emerge, while in the latter case, an "enclave" destination will develop in which the local economy will contribute little more than low-skilled labour.

\section{Precursors to Tourism Development in Ibiza and Formentera}

\subsection{An outward-looking economy}

Let us now focus on the subject of our article in geographic terms - the islands of Ibiza and Formentera, which form part of the Balearic archipelago. This larger group has always stood out clearly in the history of the Mediterranean, and if one thing has differentiated these islands from other large ones in the Mediterranean, it has been the economic interaction of the Balearics with the outside world: their decisive involvement in trade routes and international markets. The assimilation of the islands in these trading networks necessitated, firstly, the production of attractive tradable goods at competitive prices, and, secondly, the existence of a reliable exchange system (Karampela et al., 2014).

By the final decade of the $19^{\text {th }}$ Century, Ibiza had managed to kickstart its own model of economic growth based on exports of salt and almonds, to which was added a marginal manufacturing sector. This process was an essential component of the rapid growth of Spain's eastern seaboard (the Levante) and its integration with international markets, something which occurred during the first third of the $20^{\text {th }}$ Century (Martínez et al., 2015; Pinilla \& Ayuda, 2010). Although World War I had very damaging results, dismantling the intricate commercial networks which had supplied the islands with a range of essential goods, the Balearic economy recovered and, during the 1920s, became one of the most advanced in the whole of Spain (López, 2010; Rosés et al., 2010).

\subsection{Learning from Majorca}

February 9, 1903 saw the opening of the Grand Hotel in Palma de Mallorca, an exceptional establishment which bore comparison with the very finest European hotels of the day. It was accommodated in a splendid new Art Nouveau building decorated and furnished with great attention to detail, all 109 rooms featuring the very latest technological innovations, such as central heating and electric lights. Shortly after, two other first class Majorcan hotels opened their doors, likewise capable of satisfying the most demanding tourist of the hour: the Gran Hotel Marina, located in Sóller, and the Príncipe Alfonso in Cala Major, a few miles southwest of Palma (Cirer, 2012).

The seriousness with which Majorcan innovators set about exploiting the island's tourist potential is beyond all question: not only did they build and furnish large hotels, but they also 
hired the foreign professionals required to manage them (Barceló, 1966; Cirer, 2012). However, their commercial approach was fundamentally flawed, and within a short space of time it became clear that Majorca was unable to compete with Nice and Cannes in winter for long-stay, aristocratic tourists. Majorca's hotels were far from empty, though, and foreign tourists did arrive, but of a very different sort from what had originally been envisaged. Instead of wealthy, leisured rentiers, these were qualified professionals and small-to-medium size businessmen enjoying a few days of vacation on a tight budget, hoping to see a few new sights during their time abroad - the more the better. For these new tourists, Majorca delivered a beautiful medieval city, spectacular caverns, and the stunning scenery of the Serra de Tramuntana, all of them easily reachable thanks to the island's excellent transportation connections.

The process whereby hotel provision adapted itself to this new level of tourism demand was slow and faced interruptions during World War I but, in the early 1920s, Majorcan exports underwent a massive expansion which helped provide the financial backing necessary for building a second batch of large hotels (Barceló, 1966; Casasnovas \& Ginard, 2006). These high quality establishments were firmly focused on international tourism, and two of them stood out in particular: the Alhambra and the Mediterráneo hotels.

At the same time, the medical community had begun to take a positive view of exposure to the sun, sunbathing or tanning, and outdoor activities in general, turning beaches in temperate zones into a major new tourist attraction. (Hunt et al., 2012; Walton, 2000). In this case, Majorca's offering was unsurpassed; the city of Palma was surrounded by vast sandy beaches within easy reach.

Sea transport, too, witnessed a veritable revolution after 1929, when the port of Palma became the leading hub of maritime networks in the Western Mediterranean. As a result, tourists started to pour into the largest island in the Balearic group (Cirer, 2014).

Given the close contacts that existed between the two islands, Majorca's tourism success in the nineteen-twenties could hardly go unnoticed in Ibiza. After the end of World War I, Ibiza's local dailies Diario de Ibiza and La Voz reported systematically on the arrivals of cruise ships in the port of Palma, noting constantly that their arrival meant that "the hotels are fully booked and many travellers have great difficulty finding a place to stay" (Diario de Ibiza, 23/04/1923, p. 1).

\subsection{The decline of Ibiza's agriculture-based economy}

Ibiza overhauled its economy in a radical way between 1900 and 1930. During these years, change which had been gathering momentum during the second half of the $19^{\text {th }}$ Century finally crystallized, so to speak: the salt works were re-established using modern methods, new crops were introduced such as almonds and apricots, and the island's pine forests were systematically brought under exploitation, among other developments. Ibiza's natives learned to produce in order to sell, and to buy in order to eat, adopting a firmly outward-looking economic model dependant on the international markets where their main products were being sold. This dependence evinced its darker side during World War I, when the collapse of exports led to episodes of famine among the island's population, but once this crisis was over, a period of accelerated economic expansion began.

By the time the 1929 crisis hit Ibiza's exports hard, the island's economy had grown and consolidated its basis, and so was far more multifaceted and resistant than in 1914. The dynamic economic expansion in recent years had produced a significant accumulation of 
capital but, with agricultural exports languishing, it could not be invested in land or trade in raw materials and so it was necessary to seek new and imaginative alternatives. Island entrepreneurs had funds at their disposal this time, and with the collapse of traditional channels of investment and the inability to develop manufacturing, they opted for innovation in tourism - following in the path of neighbouring Majorca.

During these years, Ibiza faced a period of uncertainty which encouraged the growth of an entrepreneurial mindset capable of introducing new services and methods into the marketplace (Mayo et al., 2009; Shane \& Venkataraman, 2000). It was the very situation, the necessary breeding ground, where individuals endowed with "supernormal energy and courage to embark upon [innovation]" (Schumpeter, 1928) can enter into action.

\section{The introduction of tourism on Ibiza and Formentera}

\subsection{The first steps of tourism in Ibiza}

The success of Majorca's example was undoubtedly a key factor behind the decision of Ibizan entrepreneurs to invest in tourism. However, if they finally considered this new business feasible, it was thanks to Ibiza's own accumulation of experience in the sector in the first years of the $20^{\text {th }}$ Century.

Tourist destinations often emerge thanks to the dissemination of their name and image by pioneering tourist-adventurers, capable of reaching them and spreading the word via their literary and graphic works. The island of Ibiza had been visited by two great touristadventurers in the second half of the $19^{\text {th }}$ Century: the Archduke Luis Salvador of Austria and the Frenchman Gaston Vuillier. Both produced extensive literary descriptions of their visits and, furthermore, in profusely illustrated books, tailored to satisfy potential tourists of the age. Their engravings had a relatively wide circulation thanks to their being reproduced in numerous contemporary journals and magazines, and so it was that the name of Ibiza began to take on a certain significance (Ferrer, 2016).

The touristic upsurge witnessed by Majorca from 1903 helped to put Ibiza on the map, and it was thanks to Majorca's attractiveness that, in 1908, Ibiza's first sizeable group of tourists arrived. These were 110 Catalan hikers who, in June 1908, embarked on a cruise around the Balearics, during the course of which they dropped anchor in Ibiza harbour. The most important outcome of this excursion was the publication of the first tourist guide dedicated exclusively to Ibiza and Formentera, the Guía del turista, by Ibizan writer Arturo PérezCabrero. Published in Barcelona in 1909, it devoted particular space to the island's archaeological riches (Pérez, 1909).

Despite this, however, there was little to entice tourists to Ibiza until well into the 1920s; the maritime links with the mainland were scarce and operated by old, uncomfortable steamers, while the two small pensions in the capital were of low quality. These factors dissuaded most of the travellers who arrived in Majorca and felt a desire to visit Ibiza simply after seeing it on a map. A local journalist calculated that in the whole of 1926, only about 200 tourists came ashore on Ibiza, practically all arriving via Majorca or stopping off en route; but from then on, thanks to improvements in maritime links, the situation began to change and visitors arrived in ever greater numbers, rapidly eclipsing the previous figure. 


\subsection{Hotel establishments and hoteliers in the first phase of tourism development}

The first indication of change was the appearance of a second tourist guide devoted to the islands - Ibiza y Formentera by local journalist Bartomeu de Rosselló. Published in Barcelona in 1929, its contents were more up-to-date and less bookish than Pérez-Cabrero's. The new guide also had a shorter chapter on archaeology, fuller descriptions of local scenery and beaches, and numerous photographs and plans. One year later, in 1930, Ibiza was chosen as a stopover on the Cannes-to-Barcelona yacht race, organized by the Club de Regatas de Barcelona, an event which filled the port with unexpected visitors full of admiration. That same winter, a Majorcan travel agent, Bartomeu Mulet, announced that his company was including Ibiza on the itinerary of one of the most important cruise ships calling at Palma de Mallorca, and was making all the necessary preparations for its arrival. As a result of his efforts, the British vessel Orontes duly steamed into Ibiza harbour on May 29, 1931, with 483 tourists who came ashore.

The extraordinary economic results of these two visits spurred Ibiza's touristic ambitions to new heights, ensuring that tourism became the main topic for the local press. The Orontes had arrived at the very moment when almond and salt prices were tumbling on the international markets, and also when the island's one and only textile company was facing serious production problems. As the spectre of economic depression started to spread through Ibizan society, the solution to all the island's economic problems suddenly appeared out of the blue - tourism! The quantity and variety of the articles which appeared during these months in Ibizan newspapers and journals is impressive. Some were hopelessly naive, while others made profound analyses of the difficulties and problems involved in touristic development, highlighting the financial expertise of such writers. All agreed that there was no point in dreaming about turning Ibiza into a major tourist destination unless a hotel of international calibre was erected.

Meanwhile, tourists were arriving on their own in growing numbers, throwing the island's meagre accommodation provision into complete chaos, a situation soon noted by local innkeepers. They acted promptly, given the limited resources available to them, and within a few months had turned the crisis completely around. During the course of 1932, Ibiza Town's two traditional inns, or fondas, were joined by half a dozen new establishments. None of them could match the grand hotel called for by island newspapers, but in terms of quality they were generally adequate, being the result of serious and viable business plans aimed at meeting the era's burgeoning tourist demand. Right next to the harbour were two such establishments: the Pensión Mediterránea and the Hotel España. The first owed its existence to the initiative of two Germans who immediately launched an advertising campaign, distributing more than 20,000 leaflets in Germany and Switzerland. The Hotel España was opened by an Ibiza native, Josep Escandell, who had already worked as a hotelier in Barcelona. These establishments were short-lived, however, as in October 1932 the building that accommodated them suddenly collapsed. Escandell managed to set up his hotel again in another building, but the two Germans were not so successful.

Turning to the newly urbanised quarter of Ibiza Town (the ensanche), here the Hotel Balear opened its doors, followed shortly by another new establishment which took on the name of the defunct Pensión Mediterránea, both initiated by local entrepreneurs. Towards the end of 1932, the long-established Fonda La Marina closed its doors to undergo a complete refurbishment. In the Ibizan fishing port of Sant Antoni, the Esmeralda and Miramar fondas were enlarged and 
refurbished to offer rooms as well as meals, while Santa Eulària had the Cosme and Royalty fondas. To these hotels and inns were added several bars and restaurants. Additionally, in 1930, the first Ibizan branch of a travel agency was opened, namely the Touring Club, quickly followed by the earliest island firms catering for tourist transport by boat and bus.

Ibiza's tourist expansion lays claim to an exceptional witness, namely Walter Benjamin, who spent two summers in the vicinity of Sant Antoni (Valero, 2001). The German philosopher first arrived on the island in April 1932, attracted by the prevailing low prices, and stayed in a house by the seashore. There were almost no other visitors when he came, but as the summer advanced the little township began to fill up with foreign tourists. During the following summer, in 1933, the surge of incoming tourists amounted to a veritable boom: the bay was full of people, prices rose rapidly, and the inauguration of a large hotel was announced in the press. In a letter sent to a friend on 16 June 1933, Benjamin wrote with displeasure of the atmosphere that prevailed in Sant Antoni that summer: "Afflicted by all the horrors of the activity of newcomers and speculators, there no longer exists a secluded corner anywhere or a minute of peace" (Valero, 2001, p. 119).

Benjamin's letters only confirm what can be found in local newspapers, registering the fact that inns and pensions were all crowded, and that there were no available beds. On 14 August 1933, for example, the Diario de Ibiza reported: "Every day the influx of tourists is more clearly discernible. Almost all the Hotels [sic] are now packed."

The simultaneous expansion of all the previously existing accommodation businesses and the appearance of a dozen new inns and pensions leave no room for doubt that Ibiza, by the end of 1932, had become a basic tourism destination according to the proposed model. All of these new businesses had a clear commercial target: the foreign tourist. However, they still offered a product of limited quality, which was only suitable for visitors who were willing to accept a low level of comfort in their accommodation because they wished to get to know a destination that barely even figured yet on the map.

\section{Unexpected entrepreneurs in the second phase of Ibiza's tourism development}

\subsection{The Gran Hotel}

Throughout 1930 and during the first months of 1931, local journalists noted the presence of various hoteliers from Majorca and Catalonia who came to Ibiza to assess the island's touristic possibilities. Their arrival was regarded with enormous interest, and before long the assumption arose that one or other of them would end up building the grand hotel the island needed for tourism to really take off. Somewhat surprisingly, however, it was an Ibiza native who took the risk of creating that grand hotel - the physician Joan Villangómez Ferrer.

Joan Villangómez belonged to one of the few island families who were major landowners, and it was thanks to this that he had amassed a considerable fortune with the growth of agricultural exports after World War I. In the late 1920s, he acquired the premier site in the new urban quarter, located on the main avenue next to the port, and in 1930 began work on a large building. Although this was a major project, its objectives were strictly local, namely setting up a clinic on the first floor and renting out the ground floor as well as the second and third. Great was the surprise locally when, in September 1931, it was discovered that the initial project was being modified to accommodate a large hotel in the same building. 
It is difficult to know what induced this doctor, Joan Villangómez, to throw himself into a project about which he knew nothing, and which moreover presented certain problems and risks from the outset. There can be little doubt that the spirited journalistic campaign played a fundamental role in getting him to focus on potential opportunity rather than on obvious risks (Shane \& Venkataraman, 2000). He probably allowed himself to be swept away by the collective enthusiasm coursing through Ibizan society, whose exaggerated hopes for tourism were based more on desire than any verifiable truth, a mechanism well described by, among others, Mark Casson (1993). In short, his decision was based to some degree on factors which had little to do with finance and economics. By becoming the focus of the island's changeover to tourism, Villangómez assumed an explicit and prominent role of social leadership, backed by practically all the local politicians and businessmen. The latter had already felt obliged to declare themselves openly in favour of touristic development, given the overwhelming support it had acquired among the general public.

In a few months, the local grapevine had amplified Ibiza's touristic potential even further, and new entrepreneurs were emerging rapidly - people with no connection whatsoever with the traditional innkeepers of the island, but still willing to risk their capital in the creation of hotels. In addition to Villangómez's Gran Hotel, work began on the Hotel Buenavista in Santa Eulària promoted by Antonio Marí, and on the Hotel Portmany in Sant Antoni, initiated by Josep Roselló. A second phase, which followed immediately, added to these the Molina family's Hotel Isla Blanca in Ibiza Town, near to the Gran Hotel, and the IFA Hotel (Inglaterra-Francia-Alemania) in Formentera, promoted by Llorenç Bosch (Cirer, 2017; Serra \& Yern, 2005).

\subsection{Introduction of international hotels}

The new hotels that opened during 1933 and 1934 clearly belonged to a different category from the island's traditional fondas, both in appearance and in commercial terms. They were considerably larger and more luxurious, and did not aim to cater to visitors attracted by Ibiza's name in need of a cheap place to stay. These new businesses, on the contrary, aspired to create demand, to become the reason for the journey in the first place, with provision far exceeding what was then expected by tourists. In short, all of them were targeting a different segment of the market, hoping to attract a clientele with far greater purchasing power.

The promoters of these new hotels felt they could succeed in generating demand, but to do so, they realised it was vital to make potential customers aware of their existence in the first place. As soon as the hotels opened, each launched a striking publicity campaign, featuring business trips to European capitals, advertisements in the ports of Marseille, Algiers, Palma de Mallorca, Barcelona, and beyond. The selling features of the new hotels indicate just how ambitious and firmly grounded were the projects of Ibiza's entrepreneurs, but the Gran Hotel de Ibiza stands out above the rest. Its promoter, Joan Villangómez, made numerous business trips out of the island to acquire all the necessary components to assure that his was a hotel of quality, although it could not be regarded as a luxury hotel according to the standards of the day. Leif Borthen (2007/1967, p. 29), a Norwegian globetrotter who visited the island in the 1930s, called it "an unapproachable rich man's bastion."

The Gran Hotel was originally appointed with 72 bedrooms (later increased to 80), a modern kitchen equipped with electrical appliances, a smoking lounge, library, bar, and restaurant. All the bedrooms had hot and cold running water, and some had their own 
bathroom. To manage his establishment, Villangómez hired one of the few Ibiza natives with experience in the hotel industry, Joan Riera, who had worked in that sector during his years as an immigrant in the United States. Sensitive to the latest trends in tourism, the hotel opened a beach spa in nearby Platja d'en Bossa the summer following its inauguration, equipped with a bar-restaurant, bathing huts, wooden boardwalks, and more. On certain days, this beach spa was enlivened with music from a small orchestra, and hotel clients could get there via a bus or motor launch laid on specially for this purpose.

The Portmany and Buenavista hotel projects were very similar, both in coastal townships (Sant Antoni in the first case, Santa Eulària in the second) and near to beaches. Their size was similar -18 rooms in the former, 14 in the latter - and the buildings that accommodated each were new constructions of excellent quality. Likewise, their promoters (Josep Rosello of the Portmany and Antoni Mari of the Buenavista) had similar backgrounds, both being prominent landowners and exporters of agricultural produce from the Ibizan countryside. To round off this summary of parallels between the projects, the management was in both cases entrusted to foreign couples who were experienced professionals, German in the case of the Portmany and British in the Buenavista. The entrepreneurial approaches of these two local businessmen would appear to be a clear example of mimetic isomorphism, i.e., following the strategies of the leader (Haveman, 1993).

Formentera, for its part, saw the inauguration of the IFA hotel on the Can Marroig estate, the island's largest agricultural concern. Among the services offered to customers was a luxurious Peugeot automobile that could be used to reach the port of La Savina in order to get to Ibiza (by boat), or to make trips round the Formenteran countryside.

The last important establishment to open was the Isla Blanca Hotel, in 1934, equipped with 50 rooms and located very close to the Gran Hotel in Ibiza Town. It was not as big, and did not offer as many services as the latter, but it too occupied a new building and prided itself on quality furniture and equipment. This establishment was in the hands of the Molina family, owners of a timber sawmill as well as prominent tradesmen.

\subsection{Growth of a wide variety of hotels}

In just three years, the island of Ibiza went from offering a score of squalid lodgings at the $\mathrm{La}$ Marina and Comercio inns to showcasing 271 hotel bedrooms, a figure to which we should add the dozen bedrooms at Formentera's IFA Hotel, plus other hotels under construction which didn't manage to open before the outbreak of the Spanish Civil War. In 1935, the island could accommodate almost five hundred tourists at any time, more than half of them in hotels specifically designed to match contemporary European standards of quality.

To see what Ibiza's scale of provision really signified in these years, we can avail ourselves of data found in the 1929 Guía Oficial de Hoteles for Spain: only three Spanish coastal resorts exceeded the provision offered by Ibiza a few years later (271 rooms), namely San Sebastian, Palma de Mallorca, and Malaga (Patronato Nacional de Turismo, 1929). Palma's provision undoubtedly grew considerably between 1929 and 1935, but it is unlikely that any other Spanish resort witnessed any touristic growth during these years. Ibiza's rise is even more remarkable when we consider that its hotel provision went from zero to fourth place in just two seasons, and that most of the tourist beds on the island were completely new and in buildings specifically designed to accommodate hotels of a certain quality, meeting to the full contemporary European expectations and standards. 
Table 1. Ibiza's hotel provision in 1935. $\star$ This data is an estimate. Source: Prepared by the author.

\begin{tabular}{|l|l|l|l|}
\hline Ibiza Town & Rooms & Beds \\
\hline Year & Establishment & 7 & 12 \\
\hline$<1930$ & Pensión La Marina & 8 & 13 \\
\hline$<1930$ & Pensión El Comercio & $10^{\star}$ & $15^{\star}$ \\
\hline 1932 & Hotel Balear & 72 & 126 \\
\hline 1933 & Gran Hotel & 18 & 26 \\
\hline 1934 & Hotel España & 50 & $88^{\star}$ \\
\hline 1934 & Hotel Isla Blanca & 165 & 280 \\
\hline Total for Ibiza Town & \multicolumn{2}{|l|}{} \\
\hline Sant Antoni de Portmany & 14 & 27 \\
\hline 1932 & Pensión Esmeralda & 11 & 19 \\
\hline 1932 & Pensión Miramar & 18 & 33 \\
\hline 1933 & Hotel Portmany & 15 & 27 \\
\hline $193{ }^{\star}$ & Hotel Ses Savines & 20 & 37 \\
\hline 1935 & Hotel San Antonio & 78 & 143 \\
\hline Total for Sant Antoni & 10 & 20 \\
\hline Santa Eulària des Riu & 4 & 8 \\
\hline 1932 & Hotel Cosme & 14 & 22 \\
\hline 1932 & Hotel Royalty & 28 & 50 \\
\hline 1933 & Hotel Buenavista & 473 \\
\hline Total for Santa Eulària & 271 & \multicolumn{2}{|l|}{} \\
\hline Total for Ibiza island & \multicolumn{2}{|l|}{} \\
\hline
\end{tabular}

\section{Discussion}

In general terms, a range of public and private agents play different roles in the process of developing a tourist destination. Among the former there is usually a division between national and local administrations, while among the latter the distinction is between businessmen and the local inhabitants as a whole. We here consider the role each played in the case of Ibiza.

With regard to the authorities of the Spanish state, they were totally absent in the development of Ibiza as a tourist resort - the island was actually viewed from Madrid with the deepest suspicion (Cirer, 2019). The involvement of local authorities, on the other hand, was favourable but hardly effective, due to the scarcity of resources at their disposal rather than any lack of interest.

Turning to agents in the private sector, the direct opinion of the island's population in the 1930s cannot be known at this distance in time, but it can be gauged through the published media - in the present case, the island's three newspapers. When we look the island's two leading dailies, La Voz and Diario de Ibiza, contributors were completely in favour of touristic development, portraying local hoteliers as the leading figures in a process from which the entire population of the island would benefit. For example, La Voz published a forceful editorial on 7 May 1930 that declared: 
Let the name of Ibiza become known throughout the Mediterranean, [this is] the best way to spread knowledge of our beauty and funnel in our direction the flows of international tourism, [which will be] the main wellspring of our wealth on the day that we learn properly how to capitalise on them.

Perusing the pages of contemporary newspapers reveals a solid social consensus regarding touristic development, which was seen as an opportunity the island could not afford to squander, acclaiming hoteliers as veritable leaders of society. We should bear in mind that Spain at this time was a republic in which the press had considerable freedom of action, which means that contemporary editorials are especially valuable for assessing the attitude of the general public with regard to tourism. The three Ibizan newspapers of the day surprise us in the quality and depth of their analysis of the island's touristic potential.

What stands out when examining their pages is that the initiative of the touristic process was always in the hands of businessmen, and no one else. The population had no direct involvement in the development process, nor did it participate via political representatives, but provided unconditional tacit support. This is a highly unusual situation, which has little in common with other cases analysed in the specialist literature. In those instances, the public sector has a strong presence as a planner of the resort's development and, consequently, ends up determining the level of participation it exercises as a whole (Arnstein, 1969; Hovinen, 2002).

Any complex development process which affects an extensive social group needs "strong local leadership who coordinate activities and encourage cooperative processes" (Butler \& Weidenfeld, 2012, p. 16). In the case of Ibiza, those leaders were the innovative entrepreneurs who decided to invest in the construction of large hotels. They were the ones who transformed the island's landscape, beaches, and climate into a tourist resource that could be exploited economically. The dominance of this group of entrepreneurs should not conjure up the simplistic image of people seeking nothing but personal profit and from whom the community benefited only indirectly. After examining their frequent statements to the local press, it becomes clear that they were fully aware of the admiration their projects attracted, maintaining at all times that their concern extended far beyond personal benefit to the entire population of the island. These new hoteliers assumed the role of social leaders, and the community accepted this without any reservations. In fact, it appears perfectly legitimate to put them in the category of social entrepreneurs proposed by Thompson, Kiefer, and York, (2011, p. 211): “[I]ndividuals and organizations [who] are motivated by considerations beyond self-interest and financial returns."

One aspect that stands out in the case of Ibiza is the lack of touristic experience among all the innovators directly involved in the process. Traditional innkeepers may have had some experience, but they were not involved in the large hotel investments, which were made and directed by people completely outside the sector. This lack of experience is, in fact, a common element with other new destinations, as pointed out by authors such as Crnogaj and colleagues (2014), Jaafar et al. (2011), and Shaw (2004). An equally common feature is for tourism to appear in its earliest phase thanks to the initiative of small entrepreneurs (Ryan et al., 2012) and people positioned on the periphery of society (Russell \& Faulkner, 2004). However, this was not what took place on Ibiza: Villangómez, Roselló, and Molina all had enough capital to build and equip a large building, and all were leading and highly respected members of the island's society. 
Using the data presented, we can see that Ibiza's touristic development was led by a relatively diverse group of individuals, with varied interests and little experience - traits that might easily have led to the creation of an "incoherent tourism product" (Tolkach et al., 2013, p. 330). How did these Ibizan entrepreneurs avoid this danger? Answer: by venturing beyond the island to secure what they lacked - professional experience. All the large hotels hired foreign managers who were experts in hotel management, while they also repatriated Ibizan emigrants who had acquired touristic knowledge during their time outside the island. Also in that sense, the Ibizan innovators asserted their financial capacity to equip their new hotels with everything that was necessary.

\section{Conclusion}

In 1930, Ibiza already had a set of factors in place which acted as an enabling force for accelerated touristic development and turned the island into a potential resort. Throughout the 1920s, the steady growth of its export economy had improved communications and created a culture favourable to entrepreneurship and interaction with the outside world. When tourism expanded rapidly in Majorca, it created an expanding wave which reached a seedbed that had already been fertilised. At first, the Ibizan response was strictly adaptive, with supply growing quickly to meet the surging demand, but it still remained within familiar boundaries and limits. The inns and hostels which opened in 1931 and 1932 offered a traditional format, reflected by their small size and low quality. In general terms, it could be said that Ibiza continued to be a marginal destination, growing fast but without creating new resources and failing to appreciate the natural and heritage assets which were outside the known market. The construction of international hotels, by contrast, involved the introduction of a wide range of "created resources" in the sense proposed by Dwyer and Kim (2003, p. 379). These new resources substantially broadened the range of available activities and the range of potential customers, which now included tourists who were more affluent and less adventurous.

As had already occurred in Majorca at the beginning of the $20^{\text {th }}$ Century, the creation of Ibiza as a touristic destination did not adopt a progressive sequence of multiple phases, but followed a simple two-stage model separated by a marked difference. In the first stage, tourism developed from practically nothing, and then followed a continuous, very sharp upward trajectory. The growth was managed by traditional entrepreneurs, i.e., innkeepers, who at a certain point realized that demand was on the rise and adapted to the new situation, staying at all times within their known limits. In fact, these initial and limited investments in response to an external phenomenon created the necessary conditions for the powerful wave of investment which followed. Opportunities had become endogenous, i.e., emerging from within the island (Acs \& Audretsch, 2005).

The sequence of hotels inaugurated in 1933-1934 represented a quantitative and qualitative leap, being considerably larger while also providing standards of accommodation well above the fare laid on by traditional innkeepers, who had dominated the Ibizan scene up until that moment. In business terms, the new class of hotels meant abandoning a homemade, individualized, and diffuse mode of production and moving on to one which was welldefined, standardized, and easily recognizable to international clients. This new phase was well beyond the experience of Ibiza's entrepreneurs, requiring the taking of very great risks 
and a high tolerance of uncertainty (Crossland \& Hambrick, 2011; Engelen et al., 2015). If innovators appeared who were capable of facing up to these risks and uncertainties, it was thanks to the fact that Ibiza had developed this kind of tolerance over previous decades when it adopted an economic model dependent on international markets; a model that, it will be recalled, almost collapsed during World War I but managed to emerge once again.

The growing number of large hotel projects from 1933 onwards made possible the creation of a new ecosystem capable of offering the necessary conditions for touristic growth. It was a mechanism of self-directed and unconscious evolution, clearly Lamarckian in the sense proposed by Boschma and Lamboy (1999) and Saviotti (1996). The abundance of touristic initiatives allowed the resort of Ibiza to address different market segments, increasing the chances of success. There were both urban and beach hotels with a wide range of prices, a diverse complementary offer of bars, restaurants, excursions by boat and bus, etc. Within a remarkably short space of time a large tourist industrial district was created, capable of satisfying the demands of a wide range of potential clients, and it would have been a matter of years before the market would have selected the businesses best adapted to the demand which then existed, determining the type of tourist resort that Ibiza would have to be.

The reality, however, was somewhat different. In October 1934, turmoil in Spain escalated, the international situation in the Mediterranean worsened, and tourism began to decline to the point of total collapse in July 1936 when the Spanish Civil War broke out.

\section{Acknowledgements}

I would like to acknowledge the work of Martin Davies in translating and revising the text of the present article.

\section{References}

Acs, Z. J., \& Audretsch, D. B. (2005). Entrepreneurship, innovation and technological change. Max Planck Institute of Economics.

Armstrong, H. W., \& Read, R. (2000). Comparing the economic performance of dependent territories and sovereign microstates. Economic Development and Cultural Change, 48(2), 285-306. https://doi.org/10.1086/452459

Arnstein, S. R. (1969). A ladder of citizen participation. Journal of the American Institute of Planners, 35(4), 216-224. https://doi.org/10.1080/01944366908977225

Baldacchino, G. (2008). Studying islands: On whose terms? Some epistemological and methodological challenges to the pursuit of Island Studies. Island Studies Journal, 3(1), $37-56$.

Barceló, B. (1966). El turismo en Mallorca en la época 1925-1936. Boletín de la Cámara Oficial de Comercio Industria y Navegación de Palma de Mallorca, 651, 47-61. https://doi.org/10.5944/aldaba.16.1991.20223

Baten, J. (2003). Creating firms for a new century: Determinants of firm creation around 1900. European Review of Economic History, 7, 301-329. https://doi.org/10.1017/s136149160300011x

Becattini, G. (2004). Industrial districts. A new approach to industrial change. Edward Elgar. 
Bertram, G., \& Poirine, B. (2007). Island political economy. In G. Baldacchino (Ed.), A world of islands (pp. 325-377). Institute of Island Studies.

Besser, T. L., \& Miller, N. (2011). The structural, social, and strategic factors associated with successful business networks. Entrepreneurship \& Regional Development, 23(3-4), 113133. https://doi.org/10.1080/08985620903183728

Borthen, L. (2007). The road to San Vicente (M. Davis \& B. Lindholm, Trans.). Barbary Press. (Original work published in 1967)

Boschma, R. A., \& Lamboy, J. G. (1999). Evolutionary economics and economic geography. Journal of Evolutionary Economics, 9, 411-429.

Butler, R. W., \& Carlsen, J. (2011). Conclusions and implications for sustainable island tourism. In R. Butler \& J. Carlsen (Eds.), Island tourism: Towards a sustainable perspective, (pp. 228-237). CAB International. https://doi.org/10.1079/9781845936792.0228

Butler, R. W., \& Weidenfeld, A. (2012). Cooperation and competition during the resort lifecycle. Tourism Recreation Research, 37(1), 15-26. https://doi.org/10.1080/02508281.2012.11081684

Casasnovas, M. A., \& Ginard, D. (2006). L’Època contemporània a les Balears (1780-2005). Documenta Balear.

Casson, M. C. (1993). Cultural determinants of economic performance. Journal of Comparative Economics, 17, 418-442.

Casson, M. C., \& Lee, J. S. (2011). The origin and development of markets: A business history perspective. Business History Review, 85, 9-37. https://doi.org/10.1017/s0007680511000018

Cirer, J. C. (2020). Economic and social resilience accounts for the recovery of Ibiza's tourism sector. Tourism Geographies, Advance online publication. https://doi.org/10.1080/14616688.2020.1722214

Cirer, J. C. (2019). The crumbling of Francoist Spain's isolationism thanks to foreign currency brought by European tourists in the early years of the Golden Age. MPRA-95578. https://doi.org/10.13140/RG.2.2.33122.07369

Cirer, F. (2017). L'hotel Portmany: la utopia d'un antonienc. Editorial Mediterrània.

Cirer, J. C. (2014). Majorca's tourism cluster: The creation of an industrial district, 1919-36. Business History, 56(8), 1243-1261. https://doi.org/10.1080/00076791.2013.876532

Cirer, J. C. (2012). The beginnings of tourism in Majorca. 1837-1914. Annals of Tourism Research, 39(4), 1779-1796. https://doi.org/10.1016/j.annals.2012.06.004

Crnogaj, K., Rebernik, M., Hojnik, B., \& Gomezelj, D. O. (2014). Model of researching the sustainable entrepreneurship in the tourism sector. Kybernetes, 43(3), 377-393. https://doi.org/10.1108/k-07-2013-0155

Crossland, C., \& Hambrick, D. C. (2011). Differences in managerial discretion across countries: How nation-level institutions affect the degree to which CEOs matter. Strategic Management Journal, 32, 797-819. https://doi.org/10.1002/smj.913

Dwyer, L., \& Kim, C. (2003). Destination competitiveness: Determinants and indicators. Current Issues in Tourism, 6(5), 369-414. https://doi.org/10.1080/13683500308667962

Eckhardt, J. T., \& Shane, S. A. (2003). Opportunities and entrepreneurship. Journal of Management, 29(3), 333-349. 
Engelen, A., Schmidt, S., \& Buchsteiner, M. (2015). The simultaneous influence of national culture and market turbulence on entrepreneurial orientation: A nine-country study. Journal of International Management, 21, 18-30. https://doi.org/10.1016/j.intman.2014.12.002

Ferrer, M. C. (2016). El mite de l'Illa Blanca: les imatges d'Eivissa. Universitat de Barcelona.

Fuchs, V. R. (1965). The growing importance of the service industries. The Journal of Business, 38(4), 344-373.

Hall, P. A., \& Soskice, D. (2001). An introduction to varieties of capitalism. In P. A. Hall \& D. Soskice (Eds.), Varieties of capitalism (pp. 1-70). Oxford University Press. https://doi.org/10.1093/0199247757.003.0001

Haveman, H. A. (1993). Follow the leader: Mimetic isomorphism and entry into new markets. Administrative Science Quarterly, 38(4), 593-627. https://doi.org/10.2307/2393338

Hovinen, G. R. (2002). Revisiting the destination lifecycle model. Annals of Tourism Research, 29(1), 209-230. https://doi.org/10.1016/s0160-7383(01)00036-6

Hunt, Y., Augustson, E., Rutten, L., Moser, R., \& Yaroch, A. (2012). History and culture of tanning in the United States. In C. Heckman, J. Carolyn, \& S. L. Manne (Eds.), Shedding light on indoor tanning (pp. 5-32). Springer. https://doi.org/10.1007/978-94007-2048-0 2

Jaafar, M., Abdul-Aziz, A. R., Maideen, S. A., \& Mohd, S. Z. (2011). Entrepreneurship in the tourism industry: Issues in developing countries. International Journal of Hospitality Management, 30, 827-835. https://doi.org/10.1016/j.ijhm.2011.01.003

Karampela, S., Kizos, T., \& Spilanis, I. (2014). Accessibility of islands: Towards a new geography based on transportation modes and choices. Island Studies Journal, 9(2), 293-306.

Karampela, S., Papazoglou, C., Kizos, T., \& Spilanis, I. (2017). Sustainable local development on Aegean Islands: A meta-analysis of the literature. Island Studies Journal, 12(1), 7194. https://doi.org/10.24043/isj.6

Klyver, K., \& Foley, D. (2012). Networking and culture in entrepreneurship. Entrepreneurship \& Regional Development, 24(7), 561-588. https://doi.org/10.1080/08985626.2012.710257

López, E. (2010). El atraso económico español en el espejo europeo (1813-1914). Revista de Historia Industrial, 43, 15-64.

Martínez, J., Tirado, D. A., \& González, R. (2015). Market potential and regional economic growth in Spain (1860-1930). European Review of Economic History, 19(4), 335-358. https://doi.org/10.1093/ereh/hev014

Mayo, A. J., Nohria, N., \& Rennella, M. (2009). Entrepreneurs, managers, and leaders. Palgrave Macmillan. https://doi.org/10.1057/9780230100954

Miskell, P. (2018). Reflections on the integration of history and organization studies. Management \& Organizational History, 13(3), 213-219. https://doi.org/10.1080/17449359.2018.1550286

Mokyr, J. (2005). Long-term economic growth and the history of technology. In P. Aghion \& S. N. Durlauf (Eds.), Handbook of economic growth (pp. 1113-1180). Amsterdam. https://doi.org/10.1016/s1574-0684(05)01017-8

Mokyr, J. (1998). The second Industrial Revolution, 1870-1914. Northwestern University. 
North, D. C. (1991). Institutions. Journal of Economic Perspectives, 5(1), 97-112.

Ottati, G. (2002). Social concertation and local development: The case of industrial districts. European Planning Studies, $\quad$ 10(4), 449-466. https://doi.org/10.1080/09654310220130176

Ottati, G. (1994). Cooperation and competition in the industrial district as an organization model. European Planning Studies, 2(4), 463-484. https://doi.org/10.1080/09654319408720281

Patronato Nacional de Turismo. (1929). Guía Oficial de hoteles, pensiones, casas de viajeros, restaurantes, bares y garajes. Patronato Nacional de Turismo.

Pérez, A. (1909). Ibiza. Arte: arqueología: agricultura: comercio: costumbres: historia: industria: topografía. Guía del turista. Imprenta de Joaquín Horta.

Pinilla, V., \& Ayuda, M. I. (2010). Taking advantage of globalization? Spain and the building of the international market in Mediterranean horticultural products, 1850-1935. European Review of Economic History, 14, 239-274. https://doi.org/10.1017/s136149161000002x

Popp, A., Toms, S., \& Wilson, J. (2006). Industrial districts as organizational environments: Resources, networks and structures. Management \& Organizational History, 1(4), 349370. https://doi.org/10.1177/1744935906071909

Rosés, J. R., Martínez, J., \& Tirado, D. A. (2010). The upswing of regional income inequality in Spain (1860-1930). Explorations in Economic History, 47, 244-257. https://doi.org/10.1016/j.eeh.2010.01.002

Russell, R., \& Faulkner, B. (2004). Entrepreneurship, chaos and the tourism area lifecycle. Annals of Tourism Research, 31(3), 556-579. https://doi.org/10.1016/j.annals.2004.01.008

Ryan, T., Mottiar, Z., \& Quinn, B. (2012). The dynamic role of entrepreneurs in destination development. Tourism Planning \& Development, 9(2), 119-131. https://doi.org/10.1080/21568316.2011.630747

Sammarra, A., \& Biggiero, L. (2001). Identity and identification in industrial districts. Journal of Management and Governance, 5, 61-82.

Saviotti, P. P. (1996). Technological evolution, variety and economy. Edward Elgar.

Schettkat, R., \& Yocarini, L. (2003). The shift to services: A review of the literature. Institute for the Study of Labor (IZA).

Schumpeter, J. (1928). The instability of capitalism. The Economic Journal, 38(151), 361-386.

Serra, J., \& Yern, A. (2005). Can Marroig, mite i realitat. Editorial Mediterrània.

Shane, S. A., \& Venkataraman, S. (2000). The promise of entrepreneurship as a field of research. Academy of Management Review, 25(1), 217-226. https://doi.org/10.5465/amr.2000.2791611

Shaw, G. (2004). Entrepreneurial cultures and small business enterprises in tourism. In A. Lew, C. M. Hall, \& A. M. Williams (Eds.), A companion to tourism (pp. 122-134). Blackwell. https://doi.org/10.1002/9780470752272.ch10

Thompson, N., Kiefer, K., \& York, J. G. (2011). Distinctions not dichotomies: Exploring social, sustainable, and environmental entrepreneurship. In G. T. Lumpkin \& J. A. Katz (Eds.), Social and sustainable entrepreneurship (pp. 205-233). Emerald Books. https://doi.org/10.1108/s1074-7540(2011)0000013012 
Tolkach, D., King, B., \& Pearlman, M. (2013). An attribute-based approach to classifying community-based tourism networks. Tourism Planning \& Development, 10(3), 319-337. https://doi.org/10.1080/21568316.2012.747985

Toniolo, G. (1998). Europe's golden age, 1950-1973: Speculations from a long-run perspective. Economic History Review, 51(2), 252-267. https://doi.org/10.1111/1468$\underline{0289.00090}$

Valero, V. (2001). Experiencia y pobreza. Walter Benjamin en Ibiza, 1932-1933. Ediciones Península.

Walton, J. K. (2000). The British seaside: Holidays and resorts in the twentieth century. Manchester University Press. 